Pak. J. Agri., Agril. Engg., Vet. Sci., 2020, 36 (1): 8-12

ISSN: 1023-1072 (Print), ISSN: 2663-7863 (Online)

https://doi.org/10.47432/pjaaevs.2020.36.1.2

\title{
IMPROVEMENT OF COTTON YIELD AND FIBER QUALITY PARAMETERS IN UPLAND COTTON (GOSSYPIUM HIRSUTUM L.) GENOTYPES THROUGH CHEMICAL MUTAGEN
}

\author{
Z. A. Deho ${ }^{1^{*}}$, S. Abro and M. Rizwan \\ ${ }^{1}$ Nuclear Institute of Agriculture, Tandojam, (NIA), Pakistan
}

\begin{abstract}
Eight mutant lines developed through mutation breeding technique using chemical mutagen along with parent line (Sadori) were evaluated at NIA, experimental farm. Quantitative and qualitative traits were analyzed statistically. The chemical mutagen Ethyle Methane Sulphonate (EMS) was used at the rate of $0.03 \%$. The mutant lines (viz. NIA-M5, NIA-M10, NIA-M16, NIA-M20, NIA-M23, NIA-M29, NIA-M33 and NIA-M35) with parent Sadori were included in this study. The results revealed that three mutants (NIA-M20, NIA-M35 and NIA-M5) took (7.2\%, 8.1\% and 8.1\%) higher plant height than parent (111 $\mathrm{cm}$ ), two mutants (NIA-M5 and NIA-M20) obtained (36.8\% and 42.1\%) more sympodial branches plant ${ }^{1}$ than parent (19.0). Three mutants (NIA-M20, NIA-M5 and NIA-M10) produced $(16.8 \%, 22.4 .0 \%$ and $25.4 \%$ ) more number of bolls plant ${ }^{-1}$ than parental line (67.0). Five mutants (NIA-M5, NIA-M35, NIAM20, NIA-M23 and NIA-M29) had higher fiber length $(\mathrm{mm})(10.2 \%, 8 \%, 5.7 \%, 5 \%$ and $4.0 \%)$ as compared parent Sadori $(28.0 \mathrm{~mm})$. Two mutants (NIA-M20 and NIA-M29) showed higher fiber strength (g/tex) $(5.5 \%$ and $8.3 \%$ ) than parent (34.4\%). Two mutants (NIA-M5 and NIA-M20) produced higher seed-cotton yield $\mathrm{kg} \mathrm{ha}^{-1}(24.0 \%$ and $25.4 \%)$ over parent Sadori $\left(3563 \mathrm{~kg} \mathrm{ha}^{-1}\right)$. The selected mutant lines on the basis of higher seed-cotton yield $\left(\mathrm{kg} \mathrm{ha}^{-1}\right)$ and enhanced fiber length $(\mathrm{mm})$ compared to parent (Sadori) will be promoted in preliminary yield trials. Heritability and genetic advance were noted for early days to maturity, higher plant height $(\mathrm{cm})$, sympodial branches plant ${ }^{-1}$, length fiber $(\mathrm{mm})$, bolls plant ${ }^{-1}$ and seed-cotton yield $\left(\mathrm{kg} \mathrm{ha}^{-1}\right)$.
\end{abstract}

Keywords: cotton, fiber length, mutant, mutagen, yield

\section{INTRODUCTION}

Cotton is considered as life line of economy of Pakistan. It has a 0.8 percent share in GDP and contributes 4.5 percent in agriculture value addition (Economic Survey Report-2018-19). Mutation breeding is one of the most effective ways of inducing substantial genetic variability in plant species with desirable traits in the new mutant lines (Mei et al., 2007). The beneficial point mutations from this mutagen have resulted in the improvement of yield, quality, biotic, or abiotic tolerance of plants worldwide (IAEA, 2015). The use of induced mutation in crop upgrading has proven to be a successful approach to develop yield and quality (Bibi et al., 2009). The effectiveness of mutagenesis is considered feasible method to develop hereditary difference mainly in field crops (Hussain et al., 1982; Auld et al., 1998).

*Corresponding author: zdeho@hotmail.com
Mutagenesis has been valuable to control the cotton genome for development of quantitative and qualitative characters (Bhat and Dani, 1990). Valuable variations induced by chemical mutagen is considered useful in by passing the prolonged evolution of inclusion of exotic genes to get better fibre quality traits in cotton (Andy et al., 2004). The ethyl methane sulphonate (EMS) stimulate mutagenic efficiency and capability was noted to be genotype and mutagen reliant (Giri and Aprao, 2011). Inducing genetic distinction, mutations have been used successfully in a number of crops for breeding of agronomically important traits. Conventional mutation techniques have generally been used to improve cotton yield, fiber quality, insect pests and disease conflict in field crops. Mainly, some inexpensively important field crops viz. barley, wheat, and cotton mutant varieties which take up the majority of farm fields (Maluszynski et al., 1995). One way to induce mutation is through the use of chemical mutagens. The EMS is a 
common, powerful, and most effective chemical mutagen, especially recommended using when mutation is introduced to the seed materials, since the application and the monitoring of the outcome of mutations are relatively easy. Usually EMS in plants; causes point mutations, on the other hand, loss of a chromosome segment or deletion can also occur in lesser extent (Okagaki et al., 1991). It is significant to optimize the best probable condition to create large number of mutants having good seed germination for segregation without harmful genetic damages. Besides the wide use of mutagenesis to obtain genetic variation for plant breeding purposes, the generation of induced mutations is also applied with intentions for altering gene function with changed phenotype in basic research. The purpose was to confirm a function of a candidate gene, especially for the elucidation of biochemical, developmental, and disease resistance mechanisms (Coen and Meyerowitz, 1991). The use of chemical mutagenesis combined with modern plant breeding practices has a great potential for the future in the area of crop improvement (Percy et al., 2015). Presence of genetic variability, interrelationship and heritability of the characters provides a chance to the breeder to choose a perfect genotype directly or indirect choice of specific trait (Sadat et al., 2010).

\section{MATERIALS AND METHODS}

The commercial cotton variety Sadori was treated with EMS. The cotton seed was soaked with distilled water for eighteen hours and then soaked in $0.03 \%$ EMS solution for four hours and sown in the field. The experiment was conducted on a RCBD design with three replicates. Net plot size was maintained at $6.1 \mathrm{x}$ $6.1 \mathrm{~m}^{2}$ (eight rows of 6.09 meters). Out of eight rows, six were harvested for taking yield data. Intercultural practices like thinning, weeding, inter-culturing, fertilizer and insecticide application applied as per schedule. The data were noted on plant height $(\mathrm{cm})$, sympodial branches plant $^{-1}$, fiber length $(\mathrm{mm})$, number of bolls plant ${ }^{-1}$, fiber strength (g/tex), and seedcotton yield $\left(\mathrm{kg} \mathrm{ha}^{-1}\right)$. Lint samples were weighed and lint percentage was computed by using the following formula: Ginning out turn percentage (GOT \%) = Weight of lint in a sample/ Weight of seed-cotton in a sample $\times$ 100. The data were analyzed statistically, for LSD at $P<0.05$ after ANOVA using statistical software, Statistix. The following formula was used to estimate Heritability and Genetic Advance:

$H^{2}(\%)=\delta 2 g / \delta 2 t \times 100$

Where $\mathrm{h}^{2}=$ Heritability in broad sense, $\delta 2 \mathrm{~g}=$ induced genotypic variance and $\delta 2 t=$ Total phenotypic variance calculated from mutagen treated population.

$\mathrm{GA}(\%)=\mathrm{K} \times \delta \mathrm{p} \times \mathrm{H}$

Where, $\mathrm{GA}=$ Genetic Advance, $\mathrm{K}=2.06$ constant for selection differential $\delta p=$ phenotypic standard deviation of the mean performance of the mutated population and $\mathrm{H}=$ Heritability coefficient. The GA was expressed and percentage of the mean for the purpose of comparison.

\section{RESULTS AND DISCUSSION}

Mean squares from ANOVA for the studied characters are given in the Table 1. The data showed that mutant lines were highly significant at $P \leq 0.05$ for plant height $(\mathrm{cm})$, sympodial branches plant ${ }^{-1}$, fiber length $(\mathrm{mm})$, number of bolls plant ${ }^{-1}$, fiber strength (g/tex), and seedcotton yield $\left(\mathrm{kg} \mathrm{ha}^{-1}\right)$ representing the survival of substantial genetic unevenness along with mutant lines for different traits except that ginning out turn\% value which was nonsignificant. These results specify that the studied material is useful as genetic resources for variety development and also can be utilized for further breeding program (Faiza et al., 2017). The improving cotton and other major crops through the use of chemically induced mutants have been highly successful grown across the world (Auld et al., 1998). Chemical based mutagenesis like ethyle methane sulphonate was successful in developing change within-boll yield character as well as fiber quality parameters (Nino Brown et al., 2015). The mutagenic agents like gamma rays and EMS, proved to be highly efficient in inducing an immense amount of variability for particular trait that to in favorable direction (Patil et al., 2018).

\section{Plant height (cm)}

The data concerning plant height $(\mathrm{cm})$ revealed that mutant lines mean squares were highly significant $(P<0.05 \%)$. Results indicated that three mutants (NIA-M20, NIA-M35 and NIA-M5) showed increase in $(7.2 \%, 8.1 \%$ and $8.1 \%)$ plant height over parent $(111 \mathrm{~cm})$ (Table 1). Computations revealed 0.4352 (GCV), 21.4722 (PCV), 0.0268 ( $h^{2}$ BS) and 0.101609 (G.A as \% 
of mean) (Table 3) Mutagenic treatment has improved the plant height $(\mathrm{cm})$ for the highest phenotypic and genetic coefficients of variation; heritability and genetic advance (Siddiqui et al., 2009).

\section{Sympodial branches ( plant $^{-1}$ )}

The boll bearing branch which is called sympodial branch; is an important quantitative character that contributes to seed-cotton yield (Naimatullah et al., 2017). The sympodial branches per plant exposed that mutant lines mean squares were highly significant (Table 1). Two mutants (NIA-M5 and NIA-M20) number of increase (36.8 and $42.1 \%$ ) sympodial branches plant $^{-1}$ than parent (19.0). Data perusal revealed -0.1853(GCV), 21.5187 (PCV), -0.0861 ( $\mathrm{h}^{2} \mathrm{BS}$ ) and -0.022809 (G.A as \% of mean (Table 3) (Faiza et al., 2017).

\section{Fiber length $(\mathrm{mm})$}

The analysis of variance depicted that mutant lines mean squares also remained highly significant for fiber length $(\mathrm{mm})$. Five mutants (NIA-M5, NIA-M35, NIA-M20, NIA-M23 and NIAM29) had higher fiber length $(\mathrm{mm})(10.2 \%, 8 \%$, $5.7 \%, 5 \%$ and $4.0 \%$ ) as compared to parent line $(28.0 \mathrm{~mm})$ (Table 1). Data perusal revealed 3.9395 (GCV), 7.452 (PCV), $0.528614\left(h^{2} \mathrm{BS}\right)$ and 5.32549 G.A as \% of mean. (Maluszynski et al., 1995).
Bolls (plant ${ }^{-1}$ )

Boll weight is also imperative character which contributes to enhance seed-cotton yield. The mutagenic agent EMS, confirm to be highly proficient in inducing vast amount of variability for particular trait in positive direction. Numerous mutants were found to be better to the parents. (Patil et al., 2018). The bolls plant ${ }^{-1}$ regarding mutant lines mean square were highly significant. Three mutants (NIA-M20, NIA-M5 and NIA-M10) show increase $(16.8 \%, 22.4 .0 \%$ and $25.4 \%$ ) number of bolls plant ${ }^{-1}$ than parental line (67.0) (Table 1). Data also revealed 0.36 (GCV), 123.03 (PCV), $0.00292\left(\mathrm{~h}^{2} \mathrm{BS}\right)$ and 0.05557 (G.A as \% of mean) (Table 3). The breeder can choose a perfect genotype directly or indirectly (Sadat et al., 2010).

\section{Fiber strength (g/tex)}

The fiber strength (gram/tex) showed that mutant lines were highly significant $(P<0.05 \%)$. Two mutants (NIA-M20 and NIA-M29) showed higher fiber strength ( $\mathrm{g} / \mathrm{tex})$ increase over $(5.5 \%$ and $8.3 \%$ ) than parental line (34.4\%). Data perusal revealed 4.56 (GCV), 14.0 (PCV), 0.33 $\left(h^{2}\right.$ BS) and 2.51 G.A as \% of mean (Table 3). Ethyl methane sulphonate treatment can bring successful in improvement of fiber quality parameters especially HVI length and strength. (Deepika, et al., 2016).

Table 1. Mean square for agronomic traits of cotton mutant lines

\begin{tabular}{|l|l|l|l|l|l|l|l|l|}
\hline Source & DF & $\begin{array}{l}\text { Plant } \\
\text { height } \\
(\mathbf{c m})\end{array}$ & $\begin{array}{l}\text { Sympodial } \\
\text { branches } \\
\text { (plant }^{-1} \text { ) }\end{array}$ & $\begin{array}{l}\text { No, of } \\
\text { bolls } \\
\left.\text { (plant }^{-1}\right)\end{array}$ & $\begin{array}{l}\text { Fiber } \\
\text { length } \\
(\mathbf{c m})\end{array}$ & $\begin{array}{l}\text { Fiber } \\
\text { strength } \\
(\mathbf{g} / \text { tex })\end{array}$ & $\begin{array}{l}\text { Ginning } \\
\text { out turn } \\
(\%)\end{array}$ & $\begin{array}{l}\text { Seed-cotton } \\
\text { yield } \\
\left(\mathbf{k g ~ h a}^{-1}\right)\end{array}$ \\
\hline Rep. & 02 & 0.4815 & 0.1481 & 7.000 & 0.10815 & 0.6604 & 2.36259 & 46391 \\
\hline Mutant & 12 & $22.3426^{* *}$ & $21.1481^{* *}$ & $123.750^{* *}$ & $4.39870^{* *}$ & $15.3315^{* *}$ & $0.94176 \mathrm{~ns}$ & $315024^{\star *}$ \\
\hline Error & 24 & 1.3148 & 1.3565 & 7.667 & 0.10231 & 0.2195 & 0.73134 & 18943 \\
\hline Total & 38 & & & & & & & \\
\hline
\end{tabular}

** = Highly significant $n s=$ Non-significant

Table 2. Mean performance of upland cotton mutant lines for yield and fiber quality traits

\begin{tabular}{|c|c|c|c|c|c|c|c|}
\hline Mutant & $\begin{array}{l}\text { Plant height } \\
\text { (cm) }\end{array}$ & $\begin{array}{l}\text { Sympodial } \\
\text { branches }^{-1} \\
\left.\text { (plant }^{-1}\right)\end{array}$ & $\begin{array}{l}\text { No, of bolls } \\
\left.\text { (plant }^{-1}\right)\end{array}$ & $\begin{array}{l}\text { Fiber length } \\
(\mathrm{mm})\end{array}$ & $\begin{array}{l}\text { Fiber } \\
\text { strength } \\
\text { (g/tex) }\end{array}$ & $\begin{array}{l}\text { Ginning } \\
\text { out turn } \\
(\%)\end{array}$ & $\begin{array}{l}\text { Seed-cotton } \\
\text { yield } \\
\left(\mathrm{kg} \mathrm{ha}^{-1}\right)\end{array}$ \\
\hline NIA-M5 & 119ab & $26 a$ & $82 a b$ & $30.9 a$ & $35 c$ & $38.0 \mathrm{a}$ & $4421 \mathrm{a}$ \\
\hline NIA-M-10 & $118 b c$ & $21 \mathrm{bcd}$ & $78 b c$ & $27.2 f$ & $34 \mathrm{e}$ & $37.8 \mathrm{a}$ & $3899 b$ \\
\hline NIA-M-16 & $117 c$ & $20 \mathrm{~cd}$ & $69 d$ & $27.8 \mathrm{e}$ & $33 f$ & $37.9 a$ & $3823 b c$ \\
\hline NIA-M-20 & $120 a$ & $27 a$ & $84 a$ & 29.6 & $36 b$ & $38.8 a$ & $4468 a$ \\
\hline NIA-M-23 & $117 c$ & $22 b$ & $76 c$ & $29.4 c$ & $35 c$ & $38.9 a$ & $3915 b$ \\
\hline NIA-M-29 & $117 c$ & $21 \mathrm{bcd}$ & $68 d$ & $29.2 c$ & $37 a$ & $38.7 a$ & $3620 \mathrm{~cd}$ \\
\hline NIA-M-33 & $118 b c$ & $21 b c$ & $75 c$ & $28.4 d$ & 29.4 & $37.7 a$ & 3727bcd \\
\hline NIA-M-35 & $120 a$ & $23 b$ & $69 d$ & $30.2 b$ & $35 \mathrm{~cd}$ & $39.0 a$ & 3762bcd \\
\hline Parent & $111 d$ & $19 d$ & $67 d$ & 28.0de & 34de & $38.9 a$ & $3563 d$ \\
\hline
\end{tabular}


Table 3. Analysis of variance Error/Env, Grand Mean (GM), Genotypic Variance (GCV), Phenotypic Variance $(P C V)$, Heritability $\left(h^{2}\right)$ and Genetic Advance (GA)

\begin{tabular}{|c|c|c|c|c|c|c|c|}
\hline $\begin{array}{l}\text { Mutant lines } \\
\text { plant } \\
\text { characters }\end{array}$ & Mean M.S & $\begin{array}{l}\text { Error } \\
\text { M.S }\end{array}$ & $\begin{array}{l}\text { Grand Mean } \\
\text { (GM) }\end{array}$ & $\begin{array}{l}\text { Genotypic } \\
\text { Variance } \\
\text { (GCV) }\end{array}$ & $\begin{array}{l}\text { Phenotypic } \\
\text { Variance } \\
\text { (PCV) }\end{array}$ & $\begin{array}{l}\text { Heritability } \\
\left(h^{2}\right)\end{array}$ & $\begin{array}{l}\text { Genetic } \\
\text { advance } \\
\text { (GA) }\end{array}$ \\
\hline $\begin{array}{l}\text { Plant height } \\
\text { (cm) }\end{array}$ & 22.3426 & 21.037 & 117.48 & 0.4352 & 21.4722 & 0.0268 & 0.101609 \\
\hline $\begin{array}{l}\text { Sympodial } \\
\text { branches } \\
\left.\text { (plant }^{-1}\right)\end{array}$ & 21.1481 & 21.704 & 22.259 & -0.1853 & 21.5187 & -0.0861 & -0.22809 \\
\hline $\begin{array}{l}\text { No, of bolls } \\
\left(\text { plant }^{-1}\right)\end{array}$ & 123.750 & 122.67 & 74.222 & 0.36 & 123.03 & 0.00292 & 0.05557 \\
\hline $\begin{array}{l}\text { Fiber length } \\
(\mathrm{mm})\end{array}$ & 4.39870 & 1.6370 & 28.963 & 0.916 & 2.5536 & 0.35896 & 2.51727 \\
\hline $\begin{array}{l}\text { Fiber strength } \\
\text { (g/tex) }\end{array}$ & 15.3315 & 3.513 & 34.441 & 3.9395 & 7.452 & 0.528614 & 5.32549 \\
\hline $\begin{array}{l}\text { Ginning out turn } \\
(\%)\end{array}$ & 0.94176 & 11.7015 & 38.419 & -3.5877 & 8.1172 & -0.44190 & -4.16597 \\
\hline $\begin{array}{l}\text { Seed-cotton } \\
\text { yield }\left(\mathrm{kg} \mathrm{ha}^{-1}\right)\end{array}$ & 315024 & 303083 & 3910.8 & 3980.33 & 307063.33 & 0.012962 & 0.233445 \\
\hline
\end{tabular}

\section{Ginning out turn \%}

Mean values for ginning out turn \% of cotton is presented in Table 1. The analysis of variance for GOT \% depicted non-significant variation among the mean values at $P<0.05 \%$ level of probability. The mean values revealed that two mutant lines took increase over parental line. Data perusal revealed -3.5877 (GCV), 8.1172 (PCV), $-0.44190\left(h^{2}\right.$ BS) and -4.16597 (G.A as $\%$ of mean). Efficiency and capability was found to be genotype and mutagen reliant Giri and Aprao, (2011) agreed with our results given in Table 3.

\section{Seed-cotton yield $\left(\mathrm{kg} \mathrm{ha}^{-1}\right)$}

The results for seed-cotton yield $\left(\mathrm{kg} \mathrm{ha}^{-1}\right)$ given in theTable 1 revealed that mutant lines mean square were highly significant at $P<0.05 \%$. Two mutants (NIA-M5 and NIA-M20) produced higher seed-cotton yield $\left(\mathrm{kg} \mathrm{ha}^{-1}\right)(24.0 \%$ and $25.4 \%)$ over parental line $\left(3563 \mathrm{~kg} \mathrm{ha}^{-1}\right)$. Muthusamy and Jaybalan (2011) and Khan et al. (2014) also stated that chemical mutagen induces positive mutation to increase seed-cotton yield $\left(\right.$ plant $\left.^{-1}\right)$. Data revealed 3980.33 (GCV), 307063.33 (PCV), 0.0129 ( $\mathrm{h}^{2} \mathrm{BS}$ ) and 0.233445 (G.A as \% of mean) (Table 3 ). Valuable variations induced by chemical mutagen are considered as useful tool in by passing the prolonged progression of insertion of foreign genes to get better seedcotton yield and improved quality in cotton. These results are also comparable with the findings of Andy et al. (2004).

\section{CONCLUSION}

In this experiment, genetic variation produced and confined by selection of the treated cotton variety Sadori with EMS. Five mutants (NIA-M5, NIA-M35, NIA-M20, NIA-M23 and NIA-M29) had produced higher fiber length $(30.9,30.2,29.6$, 29.4 and $29.2 \mathrm{~mm}$, respectively) than parental line $(28.0 \mathrm{~mm})$. Two mutants (NIA-M5 and NIAM20) produced higher seedcotton yield $\mathrm{kg} \mathrm{ha}^{-1}$ (4468.3 and 4420.7) than parental line (3563.3). These mutant lines showed their superior genetic variation and boost cotton yield $\mathrm{kg} \mathrm{ha}^{-1}$ and fiber length $(\mathrm{mm})$.

\section{AUTHOR'S CONTRIBUTION}

Z. A. Deho: Writing of research paper

S. Abro: Provided technical support

M. Rizwan: Critical review

\section{REFERENCES}

Andy, D. H., D. L. Auld, M. D. Ethridge, E. F. Hequet, E. Bechere, C. J. Green and R. G. Cantrell. 2004. Inheritance of fiber quality and lint yield in a chemically mutated population of cotton. Euphytica, 136 (3): 333-339.

Auld, D. L., M. D. Ethridge, J. K. Dever and P. D. Dotray. 1998. Chemical mutagenesis as a tool in cotton improvement. In: Proceeding Beltwide Cotton Conference, San Diego, CA. 5-9 Jan. Natl. Cotton Council. Am., Memphis, TN. pp. 550-551.

Bhat, M. G. M. and R. G. Dani. 1990. Gamma Irradiation and Ethyl Methane Sulphonate induced changes in cotton seed oil content. Division of Crop Improvement, Central Institute for Cotton Research, PB No. 125, Nagpur, 440001 India.

Bibi, S., I. A. Khan, H. R. Bughio, I. A. Odhano, M. A. Asad and A. Khatri. 2009. Genetic 
differentiation of rice mutants based on morphological traits and molecular marker (RAPD). Pakistan Journal of Botany, 41 (2): 737-743.

Brown, N., C. W. Smith, S. Hague, D. Auld, E. Hequet, K. Joy and D. Jones. 2015. Within boll yield characteristics and their correlation with fiber quality parameters, following Mutagenesis of upland cotton, TAM 94L 25. Crop Science, 55 (4): 1513-1523.

Coen, E. S. and E. M. Meyerowitz. 1991. The war of the whorls: Genetic interactions controlling flower development. Nature, 353 (6339): 31-37.

Deepika, M. 2016. Improvement of cotton fiber quality with chemical mutagenesis. Ph.D. Dissertation. Texas Tech University, pp. 40.

Economic Survey Report. 2018-19. Finance Division. Government of Pakistan, pp.16.

Faiza, N., M. J. Baloch, A. W. Baloch, M. Buriro, G. S. Nizamani, M. R. Nizamani and I. A. Baloch. 2017. Genetic distance, heritability and correlation analysis for yield and fibre quality traits in upland cotton genotypes. Pakistan Journal of Biotechnology, 14 (1): 29-36.

Giri, S. P. and B. J. Apparoo. 2011. Studies on effectiveness and efficiency of EMS in pigeon pea. Cajanus cajan (L.). Bioscience Discovery, 2 (1): 29-31.

Hussain, H. A. S., F. A. Al-enani and M. ElMoghazi. 1982. Histological and morphological characteristics of a glandless cotton mutant induced with sodium azide. Egypt Journal of Genetics, 11: 167-173.

IAEA, 2015. The Joint FAO/IAEA mutant variety database.

Khan, S., M. I. Khan, A. Muhammad, F. Khan and R. A. Khan. 2014. Gamma rays induced variations in some cotton (Gossypium hirsutum L.) genotypes and their evaluation in the environment of Bannu. International Journal, 2 (10): 512518.

Maluszynski, M., B, S. Ahloowalia and B. Sigurbjörnsson. 1995. Application of In-Vivo and In-Vitro mutation techniques for crop improvement. Euphytica, 85 (1-3): 303-315.

Mei, S., Y. Wu, Y. Zhang, B. M. Liu, J. Y. Jiang, X. Xu and Z. I. Yu. 2007. Mutation of rice (Oryza sativa L.) LOX-1/2 near- isogenic lines with ion beam implantation and study of their storability. Nuclear instruments and methods in Physics Research Section B: Beam Interaction and Atoms, 265 (2): 495500.

Muthusamy, A. and N. Jayabalan. 2011. In- Vitro induction of mutation in cotton (Gossypium hirsutum L.) and isolation of mutants with improved yield and fiber characters. Acta Physiologiae Plantarum, 33 (5): 1793-1801.

Niamatullah, K., N. Ullah, I. Ullah and A. I. Shah. 2017. Yield and yield contributing traits of cotton genotypes as affected by sowing dates. Sarhad Journal of Agriculture, 33 (3): 406-411.

Okagaki, R. J., M. G. Neuffer and S. R. Wessler. 1991. A deletion common to two independently derived waxy mutations of maize. Genetics, 128 (2): 425-431.

Patil, V. S., H. V. Kalpande, V. N. Chinchane and S. K. Chavan. 2018. Studies on genetic variability for yield and yield contributing traits through induced mutation in desi cotton (Gossypium arboreum L.). International Journal of Current Microbiology and Applied Sciences, (6): 1373-1382.

Percy, R., B. Hendon, E. Bechere and D. Auld. 2015. Qualitative genetics and utilization of mutants. Cotton, 57: 155-186.

Sadat, H. A., G. A. Nematzadeh, N. B. Jelodar and O. G. Chapi. 2010. Genetic evaluation of yield and yield components at advanced generations in rapeseed (Brassica napus L.). African Journal of Agricultural Research, 5 (15): 1958-1964.

Siddiqui, M. A., I. A. Khan and A. Khatri. 2009. Induced quantitative variability by gamma rays and ethylmethane sulphonate alone and in combination in rapeseed (Brassica napus L.). Pakistan Journal of Botany, 41 (3): 1189-1195.

(Received: August 10, 2019; Accepted: May 10, 2020) 